\title{
INFORMATION SYSTEMS FAILURE EXPLAINED THROUGH THE LENS OF THE CULTURAL WEB
}

\author{
David Avison \\ ESSEC Business School, Paris, France \\ Email: avisson(a)essec.fr \\ David Wilson \\ University of Technology, Sydney, Australia \\ Email:davidw@it.uts.edu.au
}

\begin{abstract}
This paper provides a discussion of the Australian telecommunications company One.Tel Limited. The paper examines the information technology strategies employed by the company and assesses the extent to which a failure of those strategies may have contributed to, or precipitated, the downfall of the business. In particular, it looks at the company through the lens of Johnson and Scholes' (1993) cultural web. This perspective provides clear evidence of failings at the company, which were likely to have led to failure in its IT/1S policy and applications which, in turn, at least partly explains the downfall of the business.
\end{abstract}

\section{INTRODUCTION}

The paper represents our interpretation of documentation in the public domain about the collapse of the Australian telecommunications company One.Tel, much of this being from published reports, web sites, newspaper cuttings etc., along with several interviews with an IT project manager working at One.Tel during this period. In examining the elements of the Johnson and Scholes' (1993) cultural web in this context, it quotes widely from the text of Barry (2002). This cultural web model proves to be a useful tool to understand One.Tel's failure and could be used to analyse other companies.

The One.Tel company was founded in 1995, and seased trading in 2001 . During its relatively brief xistence One.Tel occupied a position in the second rank of Australian telecommunication companies. The notoriety that it gained as a result primarily of its high profile directors probably exceeded its position in the market place. One.Tel was declared insolvent in June 2001 and is now in the process of being liquidated. There is also a court case proceeding against Jodee Rich, one of the company directors.

A history of One.Tel can be found in Avison and Wilson (2002) and Barry (2002). In brief, One.Tel Limited was founded in 1995 and grew at a very substantial rate, and accomplished a great deal in a short time. The strategy in the early years was "customers not cables" (One.Tel Annual Report, 1999), as it hired the hardware and technology from other companies. However, based on the published figures, the dramatic growth in One.Tel's subscriber base in its final 18 months of trading was achieved only by incurring losses on a grand scale.

Of particular interest was the unusual culture of the company, driven by its joint managing director, Jodee Rich. It was a major differentiator compared to the competing telecommunications companies, which are much more conventional, and it was also designed to maximise staff productivity at minimum cost. We examine the company culture later through the lens of the cultural web.

One.Tel also saw itself as a very powerful marketer and brand builder. The company presented itself as young, colourful, and dynamic. It claimed that the One.Tel brand was instantly recognisable in seven countries (One.Tel Annual Report, 2000). It deliberately distanced itself as far as possible from the established telecommunications companies, whose image tends to be much more staid. It openly targeted the youth market, on the basis that young people often have no allegiance to the established carriers, were attracted by the company's youthful style, and often have substantial disposable incomes.

Much has been written in the press about the reasons for One.Tel's rapid descent into insolvency. Most of the material has focused upon the apparent failings of the company's high profile joint managing directors, Jodee Rich and Bradley Keeling. The focus on these leading players, and Lachlan Murdoch representing News Corporation 
and James Packer representing PBL (two major Australian media companies that latterly took up nearly $50 \%$ of the ownership of One.Tel), though understandable from a journalistic viewpoint, has underplayed the impact of IT failure.

\section{A BRIEF HISTORY OF THE FAILURE}

The IT strategies operating within One.Tel were not adapted to meet the rapid growth that ensued. It suggests that the methods that had served adequately in the early years, were not appropriate for the middle years. The delivery of IT systems for a fullservice large-scale telecommunications company requires a high degree of professionalism and long term planning.

\subsection{Systems Development}

Systems development at One.Tel seems to exemplify the "initial" level of maturity described by the Carnegie Mellon University's Capability Maturity Model. The characteristics of this level are "chaotic, ad hoc, heroic; unorganised, uncoordinated; high variance, unpredictable, crisis management" (Paulk et al, 1993). The teams of young and highly paid technicians at One.Tel thrived in this environment. Systems were delivered in quick time for billing, call centre, dealer management and debt collection, among many others. Only two significant systems were outsourced: the financial system and a data warehouse application used to generate key performance indicators.

Further, most of the One.Tel staff were tied into productivity bonus schemes. The bonuses that applied to the IT development staff were linked to code delivered by an agreed date. The normal case was for a developer to write and test his own code and release direct into production, all by the due date. At this point he could get the task signed off and apply for his bonus. There was a significant incentive to deliver code by a particular date no matter how shoddily written, often with no documentation, and with the most cursory testing.

It would have been more professional to have peer code review before signing off; documentation completed, checked, and filed; quality assurance completed by testing team; user acceptance (if relevant/appropriate); and managed release into production. Without these steps in place, such a bonus system is likely to deliver large amounts of shoddy bug-ridden code.

\subsection{Billing System}

The One.Tel billing system was one of the first systems to be developed when the new company commenced trading in 1995. The billing system was designed and developed entirely in-house by a team of young and enthusiastic programmers and it was a classic representation of the One.Tel approach to building systems.

In the euphoric atmosphere that prevailed within One.Tel in the early years, the systems developers acquired a high reputation and status. Every time some critical new functionality was required, the development team produced a champion who would work night and day to produce a result. However, specifications, documentation and standards suffered in this atmosphere. This lack of discipline was understandable and not unusual at this stage in the growth of the firm and its IT systems, but became problematical, particularly in the case of the billing system. Companies depend on the unfailing timeliness and accuracy of this system for their cash flow, and One.Tel was no exception. In the long term, some serious flaws in the billing system at One.Tel revealed themselves.

The first major flaw was a long-term dependence on an inadequate design. The original system was designed and developed by developers, including programmers, under conditions of great stress and urgency. It should have been viewed as only a shortterm solution. However, the basic system remained in production, relatively unchanged, until the termination of business in 2001. The system lacked flexibility, and was supported by inadequately designed database tables. It became impossible to accommodate, within the database, the complex sales plans, which were an important part of One.Tel's marketing strategy. The system became increasingly dependent upon hard-coding to provide functionality. Consequently the individual programs became exceedingly complex, and the system increasingly difficult to maintain.

The second major flaw was a lack of checks and balances. The system failed to provide the most basic financial integrity checks. It was impossible to reconcile the value of bills produced in a billing run, either backwards to the calls loaded from the carriers, or forwards to the value finally posted to the General Ledger. There were no checks at each stage of value loaded, value billed, or value posted. In the final year of its operation, the system was producing 600,000 bills per month and, apart from the most basic visual checking, the company had no means to verify their accuracy. Auditors might have demanded more rigorous controls, but according to Lecky (2001), the auditors claimed surprise at the 
company's troubles and declared that all had been well in June 2000.

The third major flaw was a lack of prioritisation and forward planning. Proper priority was not given to major enhancements required to the billing system. Two conspicuous examples of this were the implementation of the Goods and Services Tax (GST) and the introduction of the NextGen mobile service, both in 2000 . In the case of GST, not only were these changes implemented one month late, but they were so poorly executed that it caused billing run times to increase by about 50 per cent. The changes to accommodate NextGen mobile were implemented three months behind schedule, which caused the first users of the new phones to wait three months for their first bill. It would appear that sufficient resources were not allocated in time to meet critical deadlines. On each occasion the billing system suffered from these failures to plan, and the result was large numbers of seriously delayed and frequently inaccurate bills.

\subsection{Failure of IT Strategy}

As we have seen, there was a failure to recognise the weaknesses within the billing system in sufficient time to take effective corrective action. It is true that a great deal of remedial work took place in the last nine months of the system's life, but this was 'too little, too late'.

The principal strategic failure took place in 1999 when One.Tel received a massive injection of funding and started from being a junior local telecommunications company to a full-service international operation. At this time, when funds were plentiful, and substantial change and growth was in prospect, it was necessary to develop a longterm plan. However, no such planning took place, the assumption presumably being that a management-by-crisis approach could continue to deliver systems to serve the company.

Several years must have been formulated at boardroom level as much of it was published in the Annual Reports for 1999 and 2000 . For example, the following events were all clearly on the horizon:

- Significant growth on all business fronts: fixed wire, mobile, and ISP;

- Introduction of cut-price local call plans;

- Introduction of NextGen mobile;

- Introduction of GST from July 2000.

All of these changes were to have a significant impact upon the billing system, which was unable to cope with substantial increases in volume and complexity. As noted by Elliott and Gluyas (2001) "One.Tel ... failed to reinvest in the advanced customer management systems needed for a mass consumer market".

In 1999, two major projects were commenced which absorbed the majority of the IT funding and most of the talented people. These were a replacement call centre system and a database replication/fallback system. While these projects were not without merit, they were less fundamental than the billing system, which was seen as nonglamorous and technically non-challenging and was starved of resources.

As described above, the billing system survived relatively intact until the introduction of GST in July 2000 , but this caused run times to expand by around $50 \%$. The billing system depended upon one cycle being processed every three days. If the cycle processing time exceeded three days, bills were inevitably produced late. After GST, it was taking 67 days to complete a bill cycle. Further, large numbers of bills were calculated incorrectly and needed to be reprinted.

While a rectification team was trying to improve throughput, two further complications were added to the system. Firstly, the data replication team launched their solution, which further increased the load on the struggling system. Secondly, the NextGen mobile team finally completed their input to the billing system, three months behind schedule. This introduced yet more loading and another round of incorrect bills, which needed re-calculation.

At this point, late in the year 2000 , the company realised that it had a crisis on its hands and maintenance and improvement of the billing system became the absolute priority. However, the system never recovered from the GST problems in July 2000 , and from that time onwards the production of bills was always from three to six weeks behind schedule.

The progressive failure of the One.Tel billing system affected the business in a number of ways. Firstly, the delay of up to six weeks in despatching bills had a dramatic effect on cash flow. Gottliebsen (2001) calculated that the six-week delay, combined with the normal six-week delay in receiving call data records from the carriers, meant that One.Tel needed at least $\$ 120$ million extra in working capital to cover the cash flow gap. Secondly, One.Tel's billing system had a great propensity for producing incorrect bills, for reasons already described. While these were sometimes identified and corrected, often they were not. The One.Tel call centre was constantly besieged with callers making complaints about their bills, and caller waiting times became intolerable. Customers with incorrect bills who cannot gain satisfaction are not inclined to pay them. Gottliebsen (2001) further observed that slow paying customers meant an even greater strain on working 
capital and the amount was growing daily. When the company ceased trading, debtors stood at $\$ 170$ million (Trute, 2001). Of this, $\$ 75$ million was more than 120 days old, which effectively meant that these debts would never be collected.

Perhaps the most damning effect of the failure of the billing system was that it brought the company into serious disrepute. For many customers, the bill is the only regular contact that they have with their telecommunications supplier, and frequently it is all the contact they need or want. If the bills do not appear, or are suspected to be inaccurate, then there will be a general loss of confidence in the business. The media then fuelled this loss of confidence with many derisory articles about One.Tel and its problems. Some examples of adverse press have been "the billing system was appalling" (Howarth, 2001) and "some customers never even got a bill" (Elliott and Gluyas, 2001). Gottliebsen (2001) summed it up: "The One.Tel billing problems were like a fault in an aircraft. Discovered on the ground it may mean long delays, but if discovered in the air it is often fatal".

Two critical dates in the history of One.Tel are 17th May 2001, the date of the crisis board meeting, and 30th May 2001, the date the administrators were called in. Originally the major investors, News and $\mathrm{PBL}$, were going to underwrite a rights issue of $\$ 132$ million to rescue the company. However, by the end of May they had decided that the company was not salvageable. During this period the billing system was thoroughly scrutinised by PBL information technology experts. Their conclusions were not published, but it is most likely that they concluded that the system was beyond early repair. We also know that the media was full of anecdotes and witticisms about the parlous state of One.Tel's systems. Perhaps the One.Tel business may have been able to be saved, but there is a strong likelihood that News and PBL decided that One.Tel's reputation had become so tarnished that they no longer wished to be associated with it. We will now look at the failure from the viewpoint of the cultural model.

\section{ONE.TEL IN THE CONTEXT OF A CULTURAL MODEL}

Johnson and Scholes (1993) cultural web (Figure 1) has six elements around the organisational paradigm, which describes the overall picture of an organisation. We will describe each element in turn and provide examples in the specific context of One.Tel.

\subsection{Organisational structures}

Organisational structures are most clearly and traditionally evidenced in an organisation chart showing hierarchy, reporting structures and job grading. Management style, location of employees and patterns of informal contact can provide further evidence. Formal and informal organisation structures suggest other important relationships and support of power structures.

Rich is quoted in Barry (2002) as saying that One.Tel has a 'flat management structure, no hierarchies' (p64). Organisational charts were banned (p76). The directors worked in hands-on mode, and there was almost no middle management (One.Tel Annual Report, 2000). In the early days everyone sat together on 'one floor with no partitions, offices or corridors, and everyone mucked in' (p75). Although the flat management structure might have worked for 30 people it could not work for 3000 as its staff numbers became. According to Barry (p186) 'finding the person responsible for doing a particular job could be a nightmare. The telephone list didn't tell you who did what, and no one had offices, so new managers found themselves wondering down the rows of [desks], asking for people by name. The lack of job titles made it easy for people to claim that it was not their job to do what was needed'.

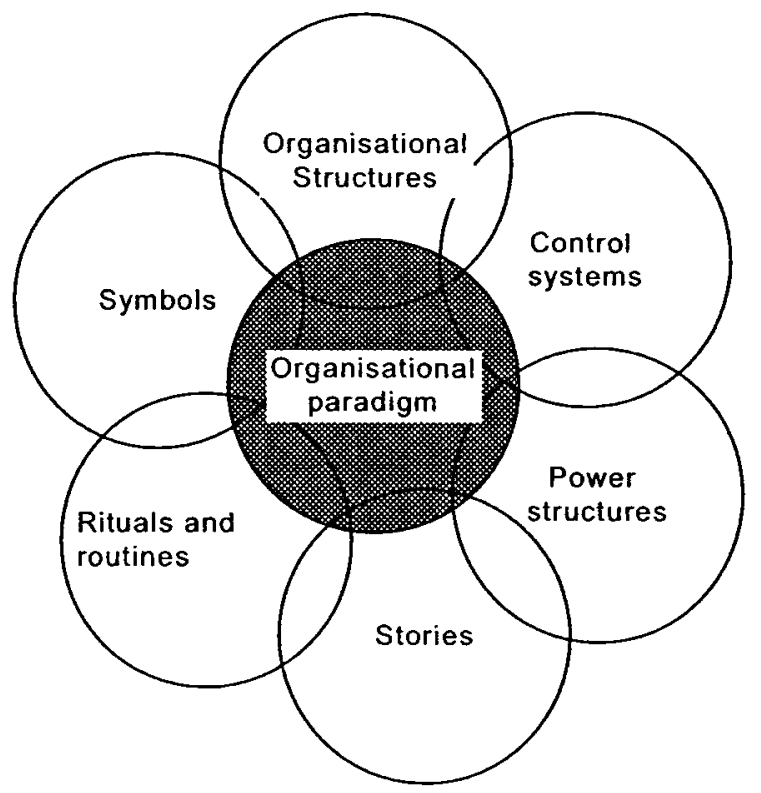

Figure 1: Cultural web (modified from Johnson and Scholes, 1993) 
One.Tel was an example of a 'Random' organization (Constantine, 2001). On the positive side it tried to be egalitarian, innovative, and exciting, while on the other side it also tended to be chaotic and unstable. Management saw their role to be that of preparing the ground for their creative people.

Compared to many organisations, the flat structure at One.Tel might be assumed to have given higher status to information systems: the IT manager reported to Rich himself. On the other hand, the lack of management structure seemed to imply a lack of status to all but Rich and his top management team.

\subsection{Control systems}

High status individuals and groups have control over resources and working practices, and the autonomy is reflected in the organisation's control systems. These include methods of appraisal and reward, promotion opportunities and grading, employee development, and methods of funding and evaluation. They support the organisational paradigm to "emphasise what is important to the organisation, and focus attention and activity' (Johnson and Scholes, 1993). The way in which IS/IT is funded, responsibility accounting relating to information systems and the way in which IS projects are justified, might be indicative of the status of the IS function.

According to Barry (2002), during the period of One.Tel's existence, it was increasingly in chaos. Neither its managers nor its systems had kept pace with its growth. One senior accountant argued that 'it was the perfect example of how not to manage a company. It was run like a family business or a fish and chip shop. It had 3000 employees, but it was still like a company with ten... The place was a joke. There were no structures, no accounting systems, no processes, and no controls' (p185).

If budget size alone were an indication of status, then IS/IT would have high status in many companies. However, Earl (1989) identifies the question of 'how much should we spend on IT' as 'the dominant concern' when attempting to resolve 'the funding issue'. However, in One.Tel, it was a lack of willingness to invest in a replacement billing system, amongst others, that proved very costly.

Regarding control of people, despite Rich's espoused philosophy of empowering people, only those people that did not stand up to him were promoted. A senior member of the finance team when discussing Rich argued that 'if you have good managers, you give away decision making. If you have yes men, you keep control. And he was a control freak' (Barry, 2002 p231).
Regarding control exercised through payment to IT staff, most of the One.Tel staff were tied into productivity bonus schemes. This fitted in well with their philosophy of driving staff to the utmost However the bonuses that applied to the IT development staff were linked to code delivered by an agreed date. The normal case was for a developer to work flat out to write and test his own code and release direct into production, all by the due date. At this point he could get the task signed off and apply for his bonus. There was thus a significant incentive to deliver code by a particular date no matter how shoddily written, with no documentation, and with the most cursory testing. Maximum productivity was encouraged at the expense of quality and thoroughness.

\subsection{Power Structures}

Power structures are not necessarily made explicit by the organisation chart, which may only imply powerful groupings, devolution of authority and influential personalities. Decision-making may be centralised, devolved throughout the organisation or exist in pockets of authority.

In relation to information systems, a powerful champion for the business unit may increase its status. Devolution of responsibility and authority throughout the organisation may provide unit heads with the ability to reflect their attitude towards IS/IT in their buying decisions. Power structures might be identified by exploring such areas as the type of decisions made by information systems professionals, how the IS/IT strategy is formulated, and the means by which IS strategy is linked to business needs.

In the euphoric atmosphere that prevailed within One.Tel in the early years, the systems developers acquired a high reputation and status. Every time some critical new functionality was required, the development team produced a champion who would work night and day to deliver a result. However, specifications, documentation and standards suffered in this atmosphere. This lack of discipline was understandable and not unusual at this stage in the growth of the firm and its IT systems, but it was problematical, particularly in the case of the billing system.

Although the general atmosphere at One.Tel was one of 'fantastic camaraderie' and 'one big happy family' with an aim to be 'fun and friendly' (Barry, 2002 pp74-75), Rich's management style was autocratic. As he told Rodney Adler, a former partner, 'either you're with me 100 per cent or you're not' ( $p 13)$. If goals set by Rich were seen as 
unrealistic, staff were told that if you can't do it then you are not the one for the job' or, worse, 'you're not a team player ... you're not a One.Tel person' (p108).

Another senior, Paul Fleetwood, remembers Rich coming to his desk with his phone light blinking and being asked 'Don't you want to work for this company? I left you a message half an hour ago and you haven't answered it. Don't let me ever see that again' (Barry, p76).

As we have seen, One.Tel's billing system could not do the job with so many new customers. The software designed for tens of thousands of customers had to cope with 750000. Barry (2002) argues (p192) that the obvious answer was to scrap the old system and build a new one, but no one in the IT department had the guts to say to Rich 'we can't make it work'.

The power structure was such that everyone around Rich was simply a 'yes man - it was a company of managers who did what they were told. 'His whole style was to intimidate' says one accountant, "he wondered why no one told him the truth. That's because when they did he would tear shreds off them' (Barry, 2002 p 231).

\subsection{Stories}

An organisation's culture may be apparent through its stories and myths. The stories that are retold may reinforce the status of a group. Such stories include those about employees who tried to 'beat the system', runaway projects, spectacular successes or failures, or the project leader who never seems to go home. The stories, through telling of the unusual, may reinforce the culture of the organisation or alienate one business unit from that culture.

There were many One.Tel stories, but one was particularly important to Rich who required that all new recruits be able to recite. They would be asked to define a team player, to which the correct answer was 'someone who enjoyed others' success and shared' (Barry, 2002 p75). The IT floor featured a Greek mythology theme, with a picture of Theseus and the Minotaur in the maze. Underneath was the moral of the story: don't be secretive (Barry, p78).

The stories told by Rich to many added up to a dream, which later proved to be a nightmare. When Murdock and Packer invested in One.Tel, they had not insisted on having their own finance director in One.Tel to look after their AU\$710 million investment. 'It appeared that they were too dazzled by the dream' (Barry, 2002 p 134).

Customers were asked to tell their One.Tel stories to friends, later these were very negative stories which obviously harmed the company. In 2001, the Ombudsman, John Pinnock, wrote to One.Tel that it is clear that there are systemic problems in dealing with customer complaints. I am also most concerned that recent letters and emails from various employees at One. Tel show a complete lack of understanding and acceptance of One.Tel's obligations ... to its customers'. Later he was to observe to the press that the company 'did not seem to care'.

\subsection{Rituals and routines}

Pentland and Rueter (1994) suggest that routines are used to explain the inertial quality of organisational structure and see them as the comerstone of theories of organisational learning and adaptation. 'Routines...are essentially complex patterns of social interaction'. The literature on routines encompasses the cognitive processes of individuals and structural and institutional constraints. Routines should not be thought of as mindless or automatic but that they are an effortful accomplishment. Routines and rituals share common roots as any moves are shaped by the physical and ritual dimensions of organisational structure as well as the need to draw on cognitive resources distributed among individuals. Pentland and Rueter (1994) argue that the enabling and continuing structures that typify organisational work situations - such as hierarchy, division of labour task-specific and situation-specific issues - naturally give rise to regular patterns of action, or routines.

Procedures and how they are followed, the organisation's rituals and routines may give an indication of what is rewarded and valued by the organisation. Martin et al. (1995) acknowledge the importance of the rituals and routines to the information systems function when suggesting that 'the new systems that work best are those that are aligned not only with the business but also with the way people think and work'. Rituals and routines might include the coffee break and the office party, but in an IS context, might also include the use or abuse of IS development methods and the conventions surrounding the interaction between IS professionals and users. As Avison and Fitzgerald (2003) argue, a methodological information systems development may be appropriate for smaller firms, but can cause many problems as the company grows.

Some aspects at One.Tel could be said to be enlightened, Rich had decreed that 'software developers should sit with the people who used [the system] so that they could see the problems first hand. And this made it user-friendly, more readily improved and more easily fixed' (Barry p75). Later, 
however, as pressures mounted things became more hectic, and according to one senior programmer 'sometimes it was not until [a software] change went live that we found out it wasn't working. Then we would have to stop the whole billing system and it would take a couple of days to correct it' (Barry, p193).

One.Tel tried very hard to build a 'can-do' mentality, where teams were encouraged to work very hard to achieve desired results. There is evidence that in the early years this approach met with considerable success. Within the IT group, for example, a number of quite sophisticated systems were developed in an unusually short time frame.

One.Tel had written 'beliefs and values' which were all about caring, sharing, positive thinking and peer review. There were no hierarchies, no job titles, no job descriptions - just missions. These stated beliefs and values included 'add and create value in everything you do', 'make it better', 'give your opinions' and (as we saw earlier) 'a happy team means happy players'. Barry $(2002, \mathrm{p} 76)$ observes that 'there was more than an element of a religion or cult about it all. And those who didn't follow the leader risked being challenged on their faith'.

One accountant who was interviewed for a job at One.Tel asked for management accounts, business plans and so on, but was told 'That's not the way we do things' (Barry, 2002 p248). He turned down the job 'as there were none of the disciplines needed to run the business'.

\subsection{Symbols}

Finally, the status of an individual or group may be evidenced in such symbols as the size and location of their office, make and model of their company car and the like. Little attention in the IS literature seems to be given to this.

Despite the apparent equality and camaraderie, at One.Tel there were teams and champions, called One.Team and One.Champ, and the champions had their pictures painted on the wall (Barry, $\mathrm{p} 75$ ). Thus the espoused organisation structure was contradicted by the symbolic pictures showing the "first among equals'. Yet another cartoon on the wall was labelled 'vitamin C', encouraging everyone to 'give tablets to one another', sharing what they knew. 'No secrets were allowed' (Barry, p76).

Some symbols suggested negative interpretations of the conventional office, thus meetings were to be minimised and to suggest their short-term nature they were known as 'huddles', perhaps around desks, known as 'pods'.

Later in the company's history, two general managers were appointed. One, George Savva, had been with the company since 1995 . He drove a Porsche, an Alpha Romeo and a Range Rover, and rode a Ducati. Rich himself was similarly keen on flashy cars and enjoyed his staff to have similar symbols, but not if they looked more impressive than his own prestigious transport!

\subsection{Organisational Paradigm}

The organisational paradigm, evident at the centre of figure 1, describes the overall picture of an organisation as supported by the cultural web. What differentiates the One.Tel case more than anything is the 'can-do' management style. The lack of a development methodology, the lack of formal documentation and specifications, the CMM Level 1 heroics, the high level of maintenance, and the quirky operating performance were not seen as failures ... on the contrary, they were lauded and championed as excellent examples of the company ethos. Only when the billing system started to cause customer complaints and not meet accounting practice was the paradigm questioned. However, it was not questioned at the top: this would be seen as a symbol of weakness. Jodee Rich concentrated very much on the big picture. Cadzow (2001) suggested his attitude was 'why bother with petty concerns like faulty billing systems ... when you can be thinking about global expansion'.

\section{CONCLUSION}

We have previously suggested (Avison and Wilson, 2002) that the failure of One.Tel had much to do with its IT failures. However, in this paper we have argued, through the use of the cultural web, that this was in turn caused by the culture of the company.

Although the organisational structure had much to commend it, being non-hierarchical and informal, this became inappropriate as the company grew and some degree of formality became essential. Although the IT manager reported to Rich himself, the lack of management structure implied a lack of status and power. In terms of control systems, there were no structures, no accounting systems, no processes, and no controls. The lack of willingness to invest in a replacement billing system, amongst others, proved very costly. Further, One.Tel IT staff were tied into productivity bonus schemes, and this led to quick but poor work, again inappropriate to the growing company. As for power structures, it 
would have been best to scrap the old system and build a new one, but no one in the IT department had the power to say this to Rich. In terms of stories and myths, the IT floor featured a Greek mythology theme, with a picture of Theseus and the Minotaur in the maze. Underneath was the moral of the story: don't be secretive. This would be an excellent myth if Rich would have taken suggestions from the IT staff seriously. Obvious rituals and routines in an IS context, include formal IS development methods which were not used in the company. Again this is the norm in a small company but causes many problems in the long run.

Thus the Johnson and Scholes model has helped us explain how a company culture might have led to IT failings (as well as company failings). This analysis suggests that the model could be used to analyse other companies' propensity for IT/IS failure.

\section{REFERENCES}

Avison, D. E. and Fitzgerald, G. (2003) Information Systems Development: Methodologies, Techniques and Tools, 3rd edition, McGraw-Hill, Maidenhead.

Avison, D. E. and Wilson, D (2002) IT Failure and the Collapse of One.Tel, In Traunmuller, R (Ed) Information Systems: The e-Business Challenge, Kluwer, pp 31-46.

Barry, P. (2002) Rich kids, Bantam, Milsons Point, NSW.

Cadzow, J. (2001): That Rich Bloke, The Australian, 4 August.

Constantine, L. (2001) The Peopleware Papers. Prentice Hall.

Earl, M.J. (1989) Management Strategies for Information Technology. Prentice Hall, Hemel Hempstead.

Elliott G. and Gluyas R. (2001): One.Tel: disconnected, The Australian, 31 May. http://www.news.com.au

Gottliebsen, R. (2001): Billing system starved One.Tel of cash, The Australian, 15 June. http://www.theaustralianit.com.au/common/storyPage/

Howarth, B. (2001): We all lose from One.Tel, Business Review Weekly, 13 July. http://www.brw.com.au/updates/codel .asp

Johnson, G. \& Scholes, K. (1993) Exploring Corporate Strategy. 3rd Edition. Prentice Hall, Hemel Hempstead.

Lecky, S. (2001): Auditors are called to account, 2 June. http://www.smh.com.au/news/0106/02/biztech/biztech 2.htm]
Martin, B.L, Batchelder, G., Newcomb, J.,. Rockart, J.F., Yetter, W.P. \& Grossman, J.H. (1995) The End of Delegation: IT and the CEO. Harvard Business Review (September-October 1995).

One.Tel Annual Report (1999): One.Tel Limited, Sydney. One.Tel Annual Report (2000): One.Tel Limited, Sydney.

Paulk, M. C., Curtis, B., Chrissis, M. B. and Weber, C. V. (1993): Capability Maturity Model, Version 1.1, IEEE Software, 10 (4), July, pp18-27.

Pentland B \& Rueter H., (1994), Organizational Routines as Grammars of Action, Administrative Science Quarterly, 39, 484-510.

Trute, P. (2001): One.Tel to close within 21 days, Daily Telegraph, 6 June. http://www.news.com.au 

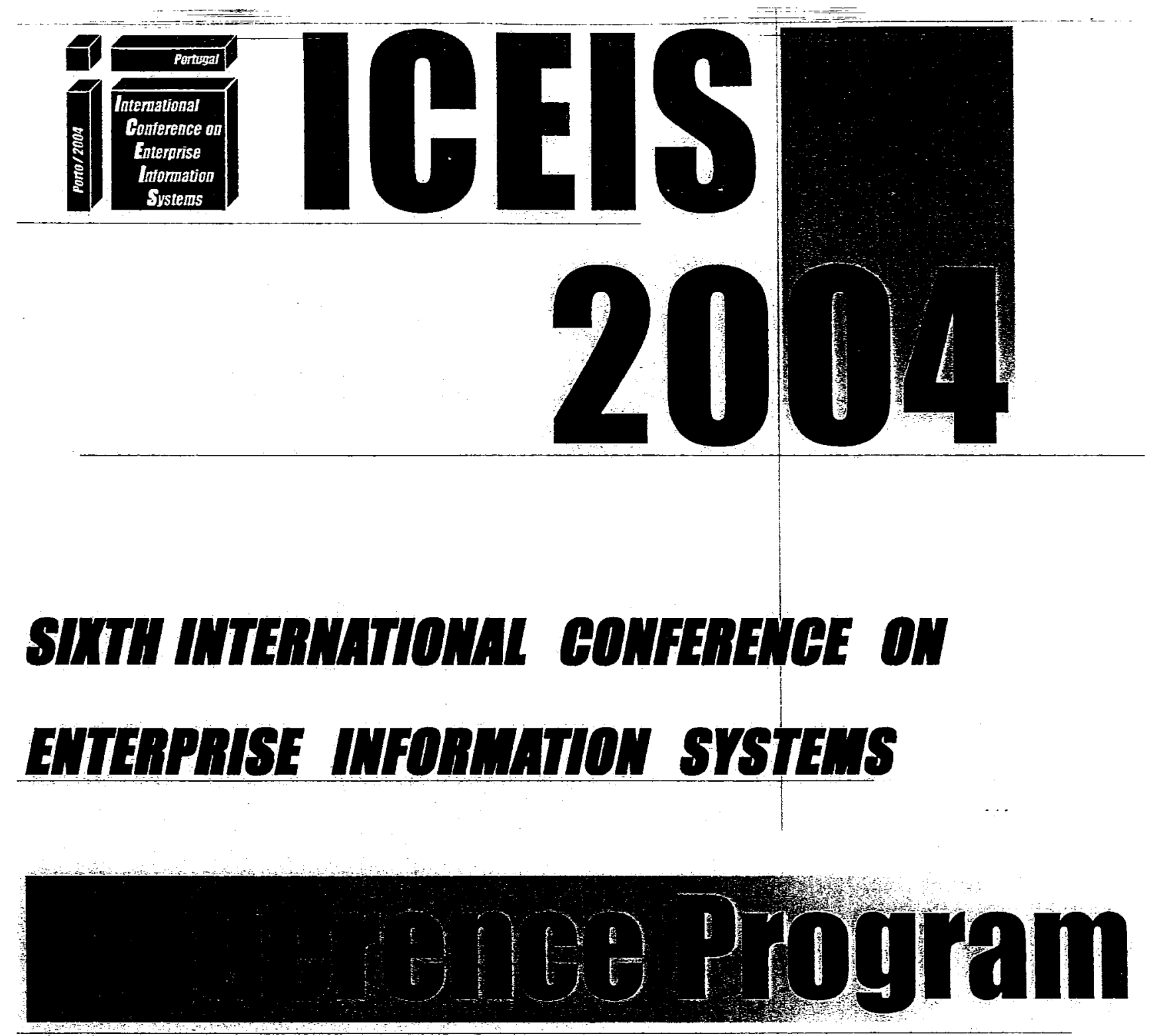

PORTO, PORTUGAL · APRIL 14-17, 2004

HOSTED BY

UNIVERSIDADE PORTUCALENSE
ORGANIZED BY

INSTICC

INSTITUTE FOR SYSTEMS and TECHNOLOGIES OF INFORMATION, CONTROL and COMMUNICATION
IN COLLABORATION WITH

ACM, AAAI, IEICE and APPIA 


\section{Organization and Steering Committees}

Honorary President

Jorge Reis Lima, Universidade Portucalense, Portugal (jrl@upt.pt)

\section{Conference co-Chairs}

Isabel Seruca, Universidade Portucalense, Portugal (iseruca@upt.pt)

Joaquim Filipe, Escola Superior de Tecnologia de Setúbal, Portugal (jilipe@iceis.org)

\section{Program co-Chairs}

Slimane Hammoudi, École Supérieure d' Electronique de l' Ouest, France (slimane.hammoudi@eseo.fr)

José Cordeiro, Escola Superior de Tecnologia de Setúbal, Portugal (jcordeiro@iceis.org) 


\section{Senior Program Committee}

Luis Amaral, University of Minho, Portugal

Peter Bøgh Andersen, University of Aalborg, Denmark

Ricardo Baeza-Yates, University of Chile, Chile

Jean Bézivin, University of Nantes, France

Enrique Bonsón, University of Huelva, Spain

João A. Carvalho, University of Minho, Portugal

Albert Cheng, University of Houston and Rice University, United States of America

Helder Coelho, FC - University of Lisbon, Portugal

Miguel Delgado, University of Granada, Spain

Jan Dietz, Delft University of Technology, The Netherlands

Frank Dignum, Utrecht University, The Netherlands

António Figueiredo, University of Coimbra, Portugal

Mark S. Fox, University of Toronto, Canada

Goran Goldkuhl, Linköping University, Sweden

Thomas Greene, MIT, United States of America

Nuno Guimarães, University of Lisbon, Portugal

Jatinder Gupta, The University of Alabama in Huntsville, United States of America

Jean-Paul Haton, University Henri Poincaré, France

Alberto Laender, Federal University of Minas Gerais, Brazil

Maurizio Lenzerini, University La Sapienza of Rome, Italy

Michel Leonard, University of Geneve, Switzerland

Kecheng Liu, University of Reading, United Kingdom

Peri Loucopoulos, University of Manchester Institute of Science and Technology, United

Kingdom

Paul Luker, Bournemouth University, United Kingdom

Kalle Lyytinen, Case Western Reserve University, United States of America

Yannis Manolopoulos, Aristotle University of Thessaloniki, Greece

José Legatheaux Martins, New University of Lisbon, Portugal

Masao Matsumoto, Kyushu Sangyo University, Japan

James Odell, James Odell Associates, United States of America

Luís Moniz Pereira, Universidade Nova de Lisboa, Portugal

Alain Pirotte, Catholique University of Louvain, Belgium

Klaus Pohl, University of Essen, Germany

Colette Rolland, University of PARIS-1, France

Bernadette Sharp, Staffordshire University, United Kingdom

Alexander Smirnov, St. Petersburg - SPIIRAS, Russia

Ronald Stamper, Staffordshire University, United Kingdom

Zahir Tari, RMIT University, Australia

Miguel Toro, University of Sevilla, Spain

José Tribolet, INESC/IST - Tecnhical University of Lisbon, Portugal

François Vernadat, European Commission, Luxembourg

Merrill Warkentin, Mississippi State University, United States of America

Hans Weigand, Tilburg University, The Netherlands

Roel Wieringa, University of Twente, The Netherlands 


\section{Secretariat Contacts}

ICEIS 2004 Secretariat

Universidade Portucalense

Departamento de Informática

Rua Dr. António Bernardino de Almeida, 541-619

4200 - 072 Porto - Portugal

Tel: +351225572512

Fax: +351225572015

E-mail:iceis2004@upt.pt

http://www.iceis.org

\section{Registration}

Workshops: Tuesday, April 13 ${ }^{\text {th }}, 8: 00$ AM - 8:30 AM.

Conference: From Wednesday, April $13^{\text {th }}$, to Saturday, April $17^{\text {th }}$, at 8:00 AM.

The registration Desk will be open every day during the conference.

\section{Meals}

Lunches will be served to all registered participants from 1:00 PM to 2:30 PM at the University Restaurant.

\section{Communications}

During the conference, the secretariat will accept messages for participants. There will be computer rooms with Internet access available for all registered participants. 
Room 309 Wednesday, 14 5:00 PM-7:00 PM

538 UNOBTRUSIVE ACQUSITION OF USER INFORMATION FOR E - COMMERCE APPLICATIONS

Oshadi Alahakoon, Seng Loke and Arkady Zaslavsky

775 AN INNOVATIVE VOCAL INTERFACE FOR AUTOMOTIVE INFORMATION SYSTEMS

Gennaro Costagliola, Sergio Di Martino, Filomena Ferrucci, Giuseppe Olivero, Umberto Montemurro and Alessandro Paliotti 435 REAL WORLD SENSORIZATION AND VIRTUALIZATION FOR OBSERVING HUMAN ACTIVITIES

Koji Kitamura, Yoshifumi Nisbida, Makoto Kimura and Hiroshi Mizoguchi 132 USER INTERFACE DESIGN FOR VOICE CONTROL SYSTEMS

Wolfgang Tschirk

\section{Room 105 Thursday, 15 9:30 AM-10:30 AM}

182 ASSESSMENT OF E-LEARNING SATISFACTION FROM CRITICAL INCIDENTS PERSPECTIVE

Nian-Shing Chen, Kan-Min Lin and Kinshute

738 PERSONALISED RESOURCE DISCOVERY SEARCHING OVER MULTTPLE REPOSITORY TYPES: USING USER AND INFORMATION PROVIDER PROFILING

Boris Rousseau, Parisch Browne, Paul Malone, Paul Foster and Venura Mendis

Room 105 Thursday, 15 11:00 AM-1:00 PM

615 EMOTION SYNTHESIS IN VIRTUAL ENVIRONMENTS

Amaryllis Raouzaiou, Kostas Karpouzis and Stefanos Kollias

381 THE MEETING OF GESTALT AND COGNITIVE LOAD THEORIES IN INSTRUCTIONAL SCREEN DESIGN

Dempsey Chang and Juhani E. Tuovinen

485 VERBS \& TOPIC MAPS: A PROPOSAL FOR LEGAL DOCUMENTATION FROM THE

DOCUMENT CONTENT ANALYSIS PERSPECTIVE

Miguel Angel Marzal, Carmen Bolaños, Jorge Morato and Francisco Calzada

740 USER ADAPTATION IN A PEDESTRIAN GUIDANCE SYSTEM FOR THE BLIND

Vivien Guillet, Beatrice Rumpler and Jean-Marie Pinon

Room $105 \sim$ Thursday, $15 \sim 2$ 2:30 PM-4:30 PM

630 ACCESSIBILITY AND VISUALLY IMPAIRED USERS

António Ramires Fernandes, Jorge Ribeiro Pereira and José Creissac Campos

254 A METHODOLOGY FOR INTERFACE DESIGN FOR OLDER ADULTS

Mary Zajicek

195 CABA2L A BLISS PREDICTIVE COMPOSITION ASSISTANT FOR AAC COMMUNICATION

SOFTWARE

Nicola Gatti and Matteo Matteuci

552 ACCESSIBLE COMPUTER INTERACTION FOR PEOPLE WITH DISABILITIES: THE CASE OF

QUADRIPLEGICS

Paula Kotze, Mariki Eloff, Ayodele Adesina-Ojo and Jan Eloff

Room 105 Thursday, 15 5:00 PM-7:00 PM

582 A CONTACT RECOMMENDER SYSTEM FOR A MEDIATED SOCIAL MEDIA

Michel Phu, Layda Agosto, Laurence Vignollet and Jean-Charles Marty

205 MANAGERIAL OPENNESS AND THE ADOPTION OF DISTRIBUTED GROUP SUPPORT

SYSTEMS: THE CASE OF WEBWIDE PARTICIPATION

John Robrbaugh

506 USABILITY HEURISTICS FOR XML-BASED WEB DEVELOPMENT

Marta Fernández de Arriba and José $A$. López Brugos

330 INTERACTIVE 3D PRODUCT ASSEMBLER FOR THE WWW - A CASE STUDY OF A 3D

FURNITURE STORE

Sopbia M K Soo and Stephen Chan 
Room 105 Friday, 16 9:30 AM-10:30 AM

566 ROBUST SPOKEN DOCUMENT RETRIEVAL BASED ON MULTILINGUAL SUBPHONETIC SEGMENT RECOGNITION

Sbi-wook Lee, Kaquyo Tanaka and Yosbiaki Itoh

484 AUTOMATIC NAVIGATIÓN AMONG MÓBILE DTV SERVICES

Cbengyuan Peng, Petri Vuorimaa

Room 105 Friday, 16 11:00 AM-1:00 PM

565 A FLEXIBLE INTERFACE ARCHITECTURE FOR DIGITAL TALKING BOOKS

Carlos Duarte, Luis Carrico and Hugo Simöes

656 CONTENT ENRICHMENT THROUGH DYNAMIC ANNOTATION

George Weir, Geonge Lepouras and Costas Vassilakis

664 MODULAR PRODUCTION OF RICH DIGITAL TALKING BOOKS

Luis Carriço, Carlos Duarte, Nuno Guimarães, António Serralheiro and Isabel Trancoso

805 COLLABORATING TO IMPROVE ERP USABILITY

Tamara Babaian, Wendy Lucas and Heikei Topi

278 HEURISTICS SUPPORTING USABLE AUTHORING TOOLS

Paula Kotzé and Elsabe Cloete

\section{Room $105 \sim$ Saturday, $17 \sim 9$ 9:30 AM-10:30 AM}

263 DEFECTS, USEFULNESS AND USABILITY OF ETHICS THEORIES IN IS ETHICS EDUCATION

Tero Vartiainen and Mikko T. Siponen

253 MANAGING EMOTIONS IN SMART USER MODELS FOR RECOMMENDER SYSTEMS

Gustavo Gonqález, Beatriz Lóper and Josep Lluis de la Rosa

Room 105 Saturday, $17 \sim$ 11:00 AM-1:00 PM

495 PREDICTING THE USER ACCEPTANCE OF PERSONALIZED INFORMATION SYSTEMS:

CASE MEDICAL PORTAL.

Seppo Pabnila

209 INFORMATTON SYSTEMS FAILURE EXPLAINED THROUGH THE LENS OF THE

CULTURAL WEB

David Avison and David Wilson

704 TOWARDS A MODEL FOR PERSONALIZED COMMUNICATION SERVICES BASED ON USER PERCEPTION

Claudia Ribeiro, Nelson Rosa and Paulo Cunba

725 USING VISUALS TO CONVEY INFORMATION

Luis Borges Gouveia

371 A COMPARATTVE SURVEY OF ACTTVITY-BASED METHODS FOR INFORMATION

SYSTEMS DEVELOPMENT

Amanda Quek and Hanifa Shab

POSTERS Thursday, $15 \sim$ 2:30 PM-4:30 PM

162 AN INVESTIGATION INTO THE REQUIREMENTS FOR AN E-LEARNING SYSTEM

Yaen Yaacov Sofer and Steve B. McIntosh

434 LEARNING BY DOING AND LEARNING WHEN DOING: DOVETAILING E-LEARNING AND DECISION SUPPORT WITH A DATA MINING TUTOR

Klaus P. Jantke, Steffen Lange, Gunter Grieser, Peter Grigoriev, Bernbard Tbalbeim and Bernd Tscbiedel 494 BASIC STRATEGIES TO ENHANCE TELEOPERATION PLATFORMS THROUGH THE INTERNET

Juan Escribano, J. A. Cerrada, Rubén Gómez and Carlos Cerrada

499 MODELLING DIALOGUES WITH EMOTIONAL INTERACTIVE AGENTS

Cveta Martinouska and Stevo Bozinouski 
POSTERS Saturday, $17 \sim 2: 30$ PM-4:30 PM

699 ACCESSING HYPERMEDIA SYSTEMS EFECTIVENESS IN LEARNING CONTEXTS

Silvina Santana and Alexander Silva

789 USABILITY OF VISUAL DATA MINING TOOLS

Edwige P. Fangseu Badjio and Francois Poulet

821 A MULTTMEDIA WORKFLOW-BASED COLLABORATTVE ENGINEERING ENVIRONMENT:

INTEGRATING AN ADAPTATIVE WORKFLOW WITH A MULTIMEDIA COLLABORATION

SYSTEM AND A COLLABORATTVE VIRTUAL ENVIRONMENT FOR PETROLEUM

ENGENEERING

Ismael Santos, Carla Valle, Alberto Raposo and Marcello Gattass

876 DICHOCOA COMMUNICATOR - SUBSYSTEM FOR BIOMEDICAL HOME SYSTEM

Rudolf Volner and Lubomir Pousele

\title{
Special Session: Digital Libraries
}

\author{
Room 205 Friday, 16 11:00 AM-1:00 PM \\ 966 PERSONALIZING DIGITAL LIBRARIES FOR EDUCATION \\ Floriana Esposito, Oriana Licchelli, Pasquale Lops and Giovanni Semeraro \\ 994 E-LIBRARY TECHNICAL SOLUTION: AN EXAMPLE OF ETU "LETI" \\ Yury Isaev and Alexey Niskovsky \\ 1081 TOOL SUPPORT FOR LEGAL ENQUIRY: FOCUS ON SPATIAL-PLANNING LAW \\ Eriks Sneiders \\ 1191 DIGITAL LIBRARY: DESIGN AND SECURITY CONSIDERATIONS \\ Stanislav Mikulecký
}

Room $205 \sim$ Friday, $16 \sim$ 2:30 PM-4:30 PM

1199 A NEW GENERATION OF DIGITAL LIBRARY TO SUPPORT DRUG DISCOVERY

RESEARCH

Edy S. Liongosari, Anatole $V$. Gershman and Mitu Singh

1205 TOWARDS THE SCHEMA HETEROGENEITY IN DISTRIBUTED DIGITAL LIBRARIES

Hao Ding and Ingeborg T. Solvberg

1232 SEMANTIC INTEGRATION OF DIGITAL LIBRARIES

José Francisco Aldana-Montes, Ismael Navas-Delgado and Maria del Mar Roldán-Garcia

452 SUPPORTING COURSE SEQUENCING IN A DIGITAL LIBRARY: USAGE OF DYNAMIC

METADATA FOR LEARNING OBJECTS

Raul Morales Salcedo and Yano Yoneo 

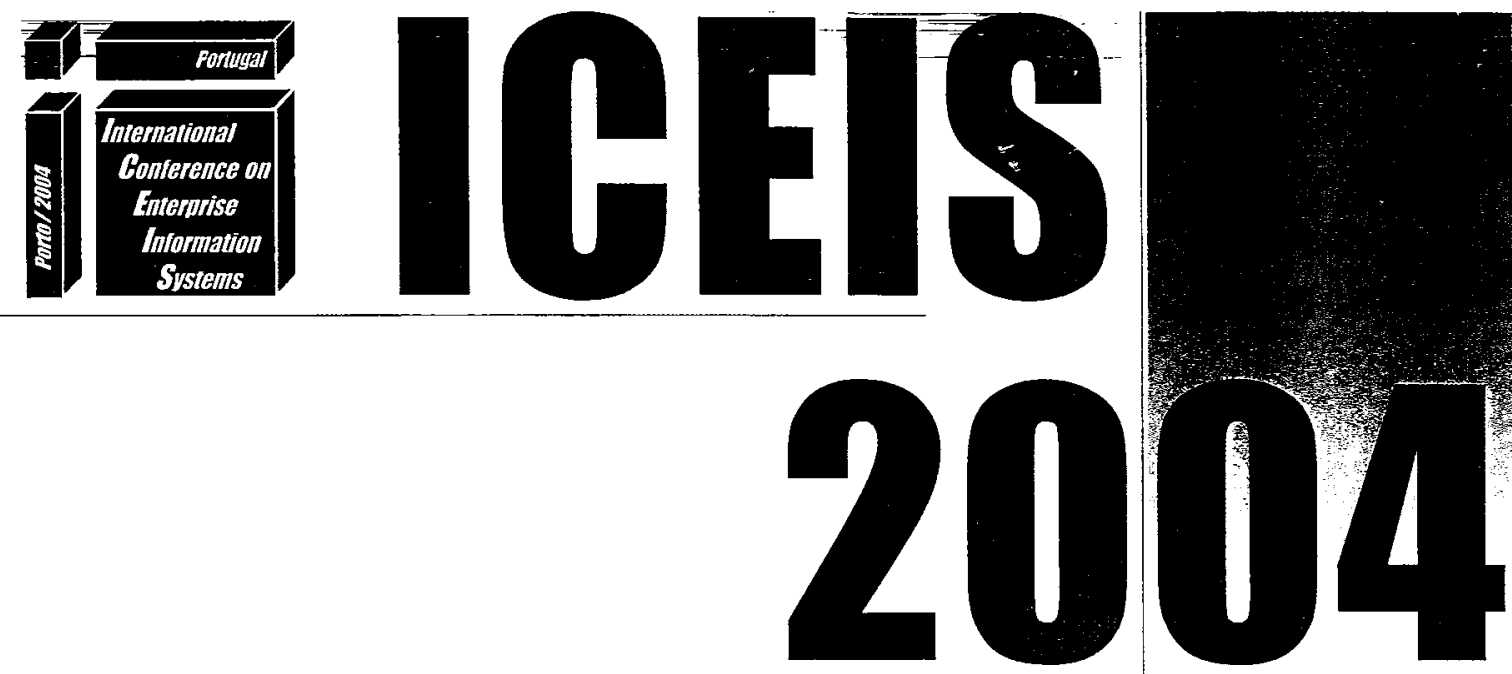

\section{SIXTH INTERNATIONAL GONFERENGE ON}

\section{ENTERPRISE INFORMATION SYSTEMS}

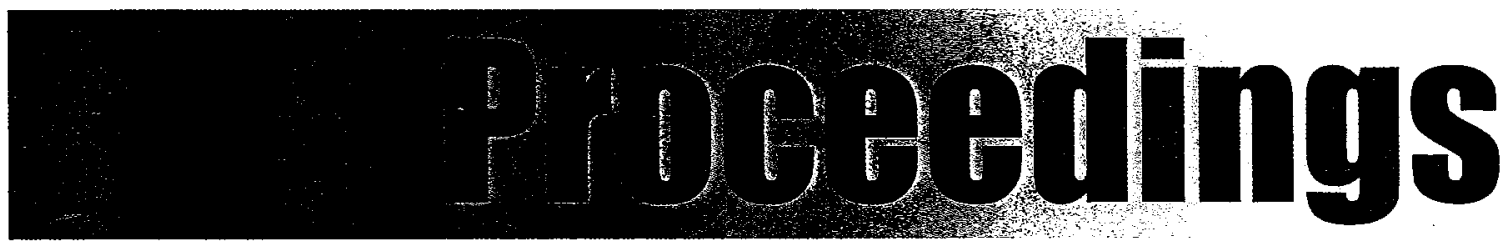

\section{Volume5}

PORTO, PORTUGAL · APRIL 14-17, 2004

HOSTED BY

UNIVERSIDADE PORTUCALENSE
ORGANIZED BY

INSTICC

INSTITUTE FOR SYSTEMS and TECHNOLOGIES OF INFORMATION, CONTROL and COMMUNICATION
IN COLLABORATION WITH

ACM, AAAI, IEICE and APPIA 
This volume contains the proceedings of the Sixth International Conference on Enterprise Information Systems (ICEIS 2004), organized by INSTICC (Institute for Systems and Technologies of Information, Control and Communication) in collaboration with PORTUCALENSE UNIVERSITY, who hosted the event.

Following the line started in 1999, ICEIS aims at becoming a major point of contact between research scientists, engineers and practitioners on the area of business applications of information systems. This year, five simultaneous tracks were held, covering different aspects related to enterprise computing, including: "Databases and Information Systems Integration", "Artificial Intelligence and Decision Support Systems", "Information Systems Analysis and Specification", "Software Agents and Internet Computing" and "Human-Computer Interaction". All tracks focus on real world applications and highlight the benefits of Information Systems and Technology for industry and services, thus making a bridge between the Academia and the Enterprise world.

Following the success of 2003, ICEIS 2004 also has a number of satellite workshops, related to the field of the conference. This year we collaborated in the organization of the following ten international workshops: 4th International Workshop on Pattern Recognition in Information Systems; 3rd International Workshop on Wireless Information Systems; 2nd International Workshop on Verification and Validation of Enterprise Information Systems; 1st International Workshop on Software Audit and Metrics; 1st International Workshop on Natural Language Understanding and Cognitive Science; 1st International Workshop on Ubiquitous Computing; 2nd International Workshop on Security In Information Systems; 1st International Workshop on Computer Supported Activity Coordination; 2nd International Workshop on Web Services: Modeling, Architecture and Infrastructure; and the 1st International Workshop on Tele-Care and Collaborative Virtual Communities in Elderly Care.

A Doctoral Consortium (DCEIS) was also prepared and held, which enabled the reunion of a set of $\mathrm{PhD}$ students and supervisors, interested in the topics of Enterprise Information Systems.

ICEIS 2004 received 605 paper submissions from 81 different countries, from all continents. 82 papers were published and presented as full papers, i.e. completed work (8 pages in proceedings / 30 ' oral presentations), 195 papers, reflecting work-in-progress or position papers, were accepted for short presentation and another 127 for poster presentation. These numbers, leading to a "full-paper" acceptance ratio below $15 \%$, show the intention of preserving a high quality forum for the next editions of this conference. Additionally, as usual in the ICEIS conference series, a number of invited talks, including keynote lectures, case studies and technical tutorials were also held. These special sessions, presented by internationally recognized specialists in different areas have definitely contributed to increase the overall quality of the Conference and to provide a deeper understanding of the Enterprise Information Systems field.

A short list of papers will be selected for a book, "Enterprise Information Systems VI", to be published by Kluwer Academic Publishers during 2004. It will be the sixth book in the series of ICEIS selectedpapers books. 


\section{FOREWORD (CONT.}

The program for this conference required the dedicated effort of many people. Firstly, we must thank the authors, whose research and development efforts are recorded here. Secondly, we thank the members of the program committee and the additional reviewers for their diligence and expert reviewing. Thirdly, we thank the invited speakers for their invaluable contribution and for taking the time to synthesise and prepare their talks. Fourthly, we thank the workshop chairs whose collaboration with ICEIS was much appreciated. Finally, special thanks to all the members of the organising committee in Porto, who collaborated admirably with the steering committee.

We wish you all an exciting conference and an unforgettable stay in the lovely city of Porto. We hope to meet you again next year in Miami (United States) for the $7^{\text {th }}$ ICEIS, details of which will be shortly made available at http://www.iceis.org.

Isabel Seruca

Portucalense University/Porto

Joaquim Filipe

EST/Setúbal

Slimane Hammoudi

ESEO/Angers

José Cordeiro

EST/Setúbal 


\section{Contents}

\section{INVITED SPEAKERS}

\section{KEYNOTE LECTURES}

ENGAGING STAKEHOLDERS IN THE DEFINITION OF STRATEGIC REQUIREMENTS

IS-3

PERICLES LOUCOPOULOS

LARGE SCALE REQUIREMENTS ENGINEERING IN ACTION: AN ETHNOGRAPHIC ANALYSIS OF FUNCTIONAL AND POLITICAL ECOLOGIES IN SITU IN SPACE MISSION PROGRAMS

KALIELYMTINEN

EVOLUTIONARY PROJECT MANAGEMENT: MULTTPLE PERFORMANCE, QUALITY AND COST METRICS FOR EARLY AND CONTINUOUS STAKEHOLDER VALUE DELIVERY

MANAGING COMPLEXITY OF ENTERPRISE INFORMATION SYSTEMS

LESZEK MACIASZEK

ORGANIZATIONAL PATTERNS: BEYOND TECHNOLOGY TO PEOPLE

COLLABORATION @ WORK:3RD WAVE OF INTERNET TO FOSTER COLLABORATION BETWEEN INDIVIDUALS ON THE SEEM

\section{Tutorials}

COMPETTTIVE ENGINEERING: A TOTALLY METRICS-BASED SYSTEM-DEVELOPMENT METHOD IS-31 Tом GII B

MODEL CHECKING AND THEOREM PROVING-BASED VERIFICATION OF EIS

IS-33

JUAN CARLOS AUGUSTO

FROM COMPONENTS TO WEB BASED SERVICES

IS-35

BALBIR S. BARN 


\section{VOL. V - HUMAN-COMPUTER INTERACTION}

UNOBTRUSIVE ACQUSITION OF USER INFORMATION FOR E - COMMERCE APPLICATIONS

Oshadi Alabakoon, Seng Loke and Arkady Zaslavsky

AN INNOVATIVE VOCAL INTERFACE FOR AUTOMOTIVE INFORMATION SYSTEMS

Gennaro Costagliola, Sergio Di Martino, Filomena Ferrucci, Giuseppe Olivero, Umberto Montemurro and Alessandro Paliotti

REAL WORLD SENSORIZATION AND VIRTUALIZATION FOR OBSERVING HUMAN

ACTIVITIES

Koji Kitamura, Yoshifumi Nisbida, Makato Kimura and Hirosbi Mizogucbi

USER INTERFACE DESIGN FOR VOICE CONTROL SYSTEMS

Wolfgang Tschirk

ASSESSMENT OF E-LEARNING SATISFACTION FROM CRITICAL INCIDENTS PERSPECTIVE Nian-Shing Chen, Kan-Min Lin and Kinshuk

PERSONALISED RESOURCE DISCOVERY SEARCHING OVER MULTIPLE REPOSITORY TYPES: USING USER AND INFORMATION PROVIDER PROFILING

Boris Rousseau, Parisch Browne, Paul Malone, Paul Foster and Venura Mendis

EMOTION SYNTHESIS IN VIRTUAL ENVIRONMENTS

Amaryllis Raouzaiou, Kostas Karpouzis and Stefanos Kollias

44

THE MEETING OF GESTALT AND COGNITIVE LOAD THEORIES IN INSTRUCTIONAL SCREEN DESIGN

Dempsey Chang and Jubani E. Tuovinen

VERBS \& TOPIC MAPS: A PROPOSAL FOR LEGAL DOCUMENTATION FROM THE DOCUMENT CONTENT ANALYSIS PERSPECTTVE

Miguel Ángel Marzal, Carmen Bolaños, Jorge Morato and Francisco Calzada

USER ADAPTATION IN A PEDESTRIAN GUIDANCE SYSTEM FOR THE BLIND

Vivien Guillet, Beatrice Rumpler and Jean-Marie Pinon

69

ACCESSIBILITY AND VISUALLY IMPAIRED USERS

António Ramires Fermandes, Jorge Ribeiro Pereira and José Creissac Campos

75

A METHODOLOGY FOR INTERFACE DESIGN FOR OLDER ADULTS

Mary Zajicek

81

CABA2L A BLISS PREDICTIVE COMPOSITION ASSISTANT FOR AAC COMMUNICATION SOFTWARE

Nicola Gatti and Matteo Matteuci

ACCESSIBLE COMPUTER INTERACTION FOR PEOPLE WITH DISABILITIES: THE CASE OF QUADRIPLEGICS

Paula Kotze, Mariki Eloff, Ayodele Adesina-Ojo and Jan Eloff 
MANAGERIAL OPENNESS AND THE ADOPTION OF DISTRIBUTED GROUP SUPPORT SYSTEMS: THE CASE OF WEBWIDE PARTICIPATION

Jobn Robrbaugh

USABILITY HEURISTICS FOR XML-BASED WEB DEVELOPMENT

Marta Fernández de Amiba and José A. López Brugos

INTERACTIVE 3D PRODUCT ASSEMBLER FOR THE WWW - A CASE STUDY OF A 3D FURNITURE STORE

Sophia $M K$ Soo and Stephen Chan

ROBUST SPOKEN DOCUMENT RETRIEVAL BASED ON MULTILINGUAL SUBPHONETIC SEGMENT RECOGNITION

Shi-wook Lee, Kazuyo Tanaka and Yoshiaki Itob

AUTOMATIC NAVIGATION AMONG MOBILE DTV SERVICES

Chengyuan Peng, Petri Vuorimaa

A FLEXIBLE INTERFACE ARCHITECTURE FOR DIGITAL TALKING BOOKS

Carlos Duarte, Luis Carrigo and Hugo Simòes

CONTENT ENRICHMENT THROUGH DYNAMIC ANNOTATION

George Weir, George Lepouras and Costas Vassilakis

MODULAR PRODUCTION OF RICH DIGITAL TALKING BOOKS

Luis Carrigo, Carlos Duarte, Nuno Guimarães, António Serralbeiro and Isabel Trancoso

COLLABORATING TO IMPROVE ERP USABILITY

Tamara Babaian, Wendy Lucas and Heikki Topi

HEURISTICS SUPPORTING USABLE AUTHORING TOOLS

Paula Kotzé and Elsabe Cloete

DEFECTS, USEFULNESS AND USABILITY OF ETHICS THEORIES IN IS ETHICS EDUCATION

Tero Vartiainen and Mikko T. Siponen

MANAGING EMOTIONS IN SMART USER MODELS FOR RECOMMENDER SYSTEMS

Gustavo González, Beatriz López and Josep Luis de la Rosa

PREDICTING THE USER ACCEPTANCE OF PERSONALIZED INFORMATION SYSTEMS: CASE MEDICAL PORTAL.

Seppo Pabnila

INFORMATION SYSTEMS FAILURE EXPLAINED THROUGH THE LENS OF THE CULTURAL WEB

David Avison and David Wilson

TOWARDS A MODEL FOR PERSONALIZED COMMUNICATION SERVICES BASED ON USER PERCEPTION

Claudia Ribeiro, Nelson Rosa and Paulo Cunba

USING VISUALS TO CONVEY INFORMATION

Luis Bonges Gouveia 
A COMPARATIVE SURVEY OF ACTIVITY-BASED METHODS FOR INFORMATION SYSTEMS DEVELOPMENT

Amanda Quek and Hanifa Shab

AN INVESTIGATION INTO THE REQUIREMENTS FOR AN E-LEARNING SYSTEM Yaen Yaacov Sofer and Steve B. McIntosh

LEARNING BY DOING AND LEARNING WHEN DOING: DOVETAILING E-LEARNING AND DECISION SUPPORT WITH A DATA MINING TUTOR

Klaus P. Jantke, Steffen Lange, Gunter Grieser, Peter Grigoriev, Bernhard Tbalbeim and Bernd Tschiedel

BASIC STRATEGIES TO ENHANCE TELEOPERATION PLATFORMS THROUGH THE INTERNET

Juan Escribano, J. A. Cerrada, Rubén Gómez and Carlos Cerrada

MODELLING DIALOGUES WITH EMOTIONAL INTERACTIVE AGENTS

Cueta Martinouska and Stevo Bozinouski

ACCESSING HYPERMEDIA SYSTEMS EFECTTVENESS IN LEARNING CONTEXTS

Silvina Santana and Alexander Silva

250

USABILITY OF VISUAL DATA MINING TOOLS

Edwige P. Fangseu Badjio and Frangois Poulet

254

A MULTIMEDIA WORKFLOW-BASED COLLABORATTVE ENGINEERING ENVIRONMENT: INTEGRATING AN ADAPTATIVE WORKFLOW WITH A MULTIMEDIA COLLABORATION SYSTEM AND A COLLABORATTVE VIRTUAL ENVIRONMENT FOR PETROLEUM ENGENEERING

Ismael Santos, Carla Valle, Alberto Raposo and Marcello Gattass

DICHOCOA COMMUNICATOR - SUBSYSTEM FOR BIOMEDICAL HOME SYSTEM

Rudolf Volner and Lubomir Pousek

TOWARDS THE DEVELOPMENT OF A GENERAL-PURPOSE DIGITAL REPOSITORY

Dimitrios A. Koutsomitropoulos, Anastasia A. Tsakou, Dimitrios $K$ Tsolis and Theodore S. Papatheodorou

PERSONALIZING DIGITAL LIBRARIES FOR EDUCATION

Floriana Esposito, Oriana Licchelli, Pasquale Lops and Giovanni Semeraro

E-LIBRARY TECHNICAL SOLUTION: AN EXAMPLE OF ETU "LETI"

Yury Isaev and Alexey Niskovsky

TOOL SUPPORT FOR LEGAL ENQUIRY: FOCUS ON SPATIAL-PLANNING LAW

Eriks Sneiders

DIGITAL LIBRARY: DESIGN AND SECURITY CONSIDERATIONS

Stanislav Mikulecky

A NEW GENERATION OF DIGITAL LIBRARY TO SUPPORT DRUG DISCOVERY RESEARCH Edy S. Liongosari, Anatole V. Gershman and Mitu Singh

TOWARDS THE SCHEMA HETEROGENEITY IN DISTRIBUTED DIGITAL LIBRARIES

Hao Ding and Ingeborg T. Solvberg 
SEMANTIC INTEGRATION OF DIGITAL LIBRARIES

José Francisco Aldana-Montes, Ismael Navas-Delgado and Maria del Mar Roldán-Garcia

SUPPORTING COURSE SEQUENCING IN A DIGITAL LIBRARY: USAGE OF DYNAMIC METADATA FOR LEARNING OBJECTS

Raul Morales Salcedo and Yano Yoneo 